\title{
Application of Water Quality Identification Index to Water Quality Assessment on West Lake of Guangdong Ocean University
}

\author{
Yayun Liu ${ }^{a}$, Canfu Xiao ${ }^{b}$ \\ a College of Chemistry and Environment, Guangdong Ocean University, Zhanjiang, China \\ b College of Economy and management, Guangdong Ocean University, Zhanjiang, China
}

aliu ya yun@126.com, bxcf.123 @.com

Keywords: water quality assessment, water quality identification index, West Lake

Abstract. This study was carried out to evaluate the water quality of West Lake in Guangdong Ocean University with the method of single factor and comprehensive water quality identification index based on the data investigated from four sampling sites in May, September and December of 2013 and March of 2014. The results indicated that: The main pollutants of West Lake are total phosphorus (TP), total nitrogen (TN) and permanganate index $\left(\mathrm{COD}_{\mathrm{Mn}}\right)$. TP is the key pollutant of West Lake. The single factor water quality identification index of TP is from 6.21 to 9.44. The water quality is worse than the national quality standards for Class $\mathrm{V}$ in all the monitoring sites and time. The water quality of TP is 1 to 4 grade worse than water environment function zone of West Lake . The water quality shows regular change trend in different monitoring time. The water quality at wet season, i.e. May and September is better than that at dry season, i.e. December and March. The highest comprehensive water quality identification index value of 6.331 appears in December, and the lowest is 4.310 in September. The main influence factor of the water quality is the external source of pollution from the domestic sewage of the dormitory and cafeteria. Strengthen the management of the domestic sewage is the valid measure to improve the water quality of West Lake.

\section{Introduction}

West Lake is located in the west campus of Guangdong Ocean University. As one of the two important wetland landscape in the campus, West Lake provides a special function of ecological environment and campus service for the university. However, the water quality of West Lake faces a serious threat with the domestic sewage of the dormitory and cafeteria put into the lake without any treatment. It is necessary to evaluate the water quality of West Lake. The method of water quality identification index were frequently applied to evaluate the water quality of lakes ${ }^{[1-5]}$. It is a valuable tool for lake management in China ${ }^{[1]}$. The comprehensive quality information can be completely expressed by both the single factor and comprehensive water quality identification index. Not only the qualitative assessments but also the quantitative assessments can be made if they integrated together ${ }^{[6]}$. Based on the water quality monitoring data in May, September and December of 2013 and March of 2014, the water environment quality of West Lake was assessed with the method of water quality identification index. The results obtained in this study will provide support for the improvement and rehabilitation of West Lake water quality in Guangdong Ocean University.

\section{Materials and Methods}

Sample Collection and Analysis. Four monitoring sites were settled in West Lake of Guangdong Ocean University. Surface waters were collected in May, September and December in 2013 and March in 2014. Eight monitoring item including water temperature, $\mathrm{pH}$, dissolved oxygen(DO), permanganate index $\left(\mathrm{COD}_{\mathrm{Mn}}\right)$, chemical oxygen demand $\left(\mathrm{COD}_{\mathrm{Cr}}\right)$, ammonia nitrogen $\left(\mathrm{NH}_{3}-\mathrm{N}\right)$, total phosphorus (TP) and total nitrogen (TN) were surveyed. The samples were analyzed by standard procedure ${ }^{[7]}$.

Water quality evaluation method. The water quality of West Lake was evaluated with the method of single factor and comprehensive water quality identification index ${ }^{[8-9]}$. As a kind of special campus landscape system, the water quality of West Lake needs to meet the request of Class $V$ function 
zone $^{[7]}$.

\section{Results and Discussion}

Water quality characters. The monitoring data of water quality of West Lake during different monitoring time are presented in Table1 and highlighted as follow:

DO were surveyed in this study. The quality of the water is better with the higher concentration of DO. As shown in Table 1, the range of DO values is from 2.06 to $8.23 \mathrm{mg} / \mathrm{l}$. All of the sampling sites meet the national quality standards for Class V. The highest average value of DO is in September with $6.85 \mathrm{mg} / \mathrm{l}$, conforming to the national quality standards for Class II. The lowest average value is in December with $4.12 \mathrm{mg} / \mathrm{l}$, achieving the national quality standards for Class IV. The value of DO is more than $5 \mathrm{mg} / \mathrm{l}$ indicating the healthy state of the lake. In spite of December ,the west lake is in healthy state.

As the index of organic compounds, $\mathrm{COD}_{\mathrm{Mn}}$ and $\mathrm{COD}_{\mathrm{Cr}}$ were surveyed in this study. As shown in Table 1, all of the sampling sites of $\mathrm{COD}_{\mathrm{Cr}}$ reach the national quality standards for Class $\mathrm{V}$ ranging from 13.83 to $32.03 \mathrm{mg} / \mathrm{l}$. The lowest average concentration of $\mathrm{COD}_{\mathrm{Cr}}$ is in May with $15.40 \mathrm{mg} / \mathrm{l}$, conforming to the national quality standards for Class III. The average concentration of $\mathrm{COD}_{\mathrm{Cr}}$ in the other monitoring time meet the national quality standards for Class IV . COD $\mathrm{Mn}_{\mathrm{n}}$ is different from $\mathrm{COD}_{\mathrm{Cr}}$. None of the sampling sites are able to achieve the national quality standards for Class $\mathrm{V}$ in March and December. The range is from 15.03 to 18.12 , and the average concentration of COD $_{\mathrm{mn}}$ is $16.64 \mathrm{mg} / \mathrm{l}$ and $16.48 \mathrm{mg} / \mathrm{l}$ respectively. All of the sampling sites meet the national quality standards for Class V in May and September.

Table 1 Investigating data of West Lake during monitoring time (mg/l)

\begin{tabular}{|c|c|c|c|c|c|c|c|}
\hline Month & & DO & $\mathrm{COD}_{\mathrm{Cr}}$ & $\mathrm{COD}_{\mathrm{Mn}}$ & $\mathrm{NH}_{3}-\mathrm{N}$ & $\mathrm{TN}$ & TP \\
\hline \multirow{2}{*}{ May } & Range & $5.21 \sim 6.77$ & $13.83 \sim 16.34$ & $7.29 \sim 13.45$ & $0.56 \sim 0.88$ & $1.31 \sim 1.92$ & $0.33 \sim 0.66$ \\
\hline & Ave. & 5.92 & 15.40 & 12.07 & 0.70 & 1.65 & 0.50 \\
\hline \multirow{2}{*}{ Sep. } & Range & $5.47 \sim 8.23$ & $18.17 \sim 23.39$ & $8.39 \sim 13.54$ & $0.31 \sim 0.47$ & $1.33 \sim 1.58$ & $0.18 \sim 0.31$ \\
\hline & Ave. & 6.85 & 21.21 & 11.45 & 0.41 & 1.44 & 0.25 \\
\hline Wet & Season & 6.38 & 18.30 & 11.61 & 0.55 & 1.54 & 0.37 \\
\hline \multirow[t]{2}{*}{ Dec. } & Range & $2.06 \sim 7.93$ & $24.16 \sim 32.03$ & $15.38 \sim 17.43$ & $1.86 \sim 1.96$ & $4.02 \sim 5.16$ & $0.73 \sim 0.96$ \\
\hline & Ave. & 4.12 & 27.58 & 16.48 & 1.91 & 4.55 & 0.87 \\
\hline \multirow{2}{*}{ Mar. } & Range & $5.12 \sim 6.01$ & $19.45 \sim 29.01$ & $15.03 \sim 18.12$ & $0.48 \sim 0.61$ & $1.76 \sim 2.32$ & $0.36 \sim 0.81$ \\
\hline & Ave. & 5.63 & 21.43 & 16.64 & 0.53 & 2.14 & 0.65 \\
\hline Dry & Season & 4.87 & 24.5 & 16.56 & 1.22 & 3.34 & 0.76 \\
\hline
\end{tabular}

Nutrients included $\mathrm{NH}_{3}-\mathrm{N}$ TN and TP were investigated in this study. As shown in Table1,the concentrations of $\mathrm{NH}_{3}-\mathrm{N}$ is from 0.31 to $1.96 \mathrm{mg} / \mathrm{l}$, reaching the national quality standards for Class $\mathrm{V}$. In September, the concentrations of $\mathrm{NH}_{3}-\mathrm{N}$ conform to the national quality standards for Class II, and the value is from 0.31 to 0.47 . The average value of $\mathrm{NH}_{3}-\mathrm{N}$ in March and May reached the national quality standards for Class III with 0.53 and $0.70 \mathrm{mg} / \mathrm{l}$, respectively. The average concentrations of TN in March and December are unable to arrive at the national quality standards for Class V. The average value is 2.14 and $4.55 \mathrm{mg} / \mathrm{l}$, respectively. The average value of TN is 1.44 and $1.65 \mathrm{mg} / \mathrm{l}$ in September and May, respectively which meet the national quality standards for Class IV and Class V. The trend of TP appears the same as TN. However, the concentrations of TP in all the monitoring stations and all the monitoring times are unable to reach the national quality standards for Class V . 
The water quality of West Lake at different seasons are presented in Table1. All the monitoring items appears the same trend as follow: The water quality at wet season is better than that at dry season. At wet season, all the items reach the national quality standards for Class V except TP. TN and $\mathrm{COD}_{\mathrm{Mn}}$ reach the national quality standards for Class V. $\mathrm{NH}_{3}-\mathrm{N}$ and $\mathrm{COD}_{\mathrm{Cr}}$ reach Class III. And DO reach Class II. However, at dry season, TN, TP and $\mathrm{COD}_{\mathrm{Mn}}$ are unable to confirm to the national quality standards for Class V. $\mathrm{NH}_{3}-\mathrm{N}$ and $\mathrm{COD}_{\mathrm{Cr}}$ reach Class IV. And DO reach Class III. Over all, the water quality of West Lake at wet season is one class better than that at dry season.

Water quality assessment The water quality of West Lake in different monitoring time was assessed with the method of single factor water quality identification index $(P i)$ and comprehensive water quality identification index $\left(I_{w q}\right)$. The results are presented in Table 2 and highlighted as follow:

Seen from the assement result of the single factor water quality identification index (Pi), TP, TN and $\mathrm{COD}_{\mathrm{Mn}}$ are the main pollutants of West Lake. $P_{i}$ of TP is from 6.21 to 9.44 . The water quality is worse than the national quality standards for Class $\mathrm{V}$ in all the monitoring time ${ }^{[8]}$. The water quality of TP is the worest In December. Pi of TP is 9.44 indicating that the water quality of TP is 4 grade worse than water environment function zone of West Lake ${ }^{[8]}$. TN and COD $\mathrm{Mn}_{\mathrm{n}}$ appear the same trend. The water quality is worse than the national quality standards for Class V in March and December. In December and March, $P i$ of TN is 7.32 and 6.11, respectively. The water quality of TN is 2 and 1 grade worse than water environment function zone of West Lake in December and March ${ }^{[8]}$. Pi of $\mathrm{COD}_{\mathrm{Mn}}$ in March and December is the same with 6.11, indicating thant the water quality of COD $\mathrm{Mn}$ is 1 class worse than water environment function zone of West Lake. In May and September, TN and $\mathrm{COD}_{\mathrm{Mn}}$ met the request of the water environment function zone of West Lake.

As shown in Tabel 2, $\mathrm{COD}_{\mathrm{Cr}}, \mathrm{NH}_{3}-\mathrm{N}$ and $\mathrm{DO}$ reach the request of the water environment function zone of West Lake. In September the water quality of $\mathrm{NH}_{3}-\mathrm{N}$ and $\mathrm{DO}$ conform to the national quality standards for Class II. And the water quality of $\mathrm{NH}_{3}-\mathrm{N}$ and $\mathrm{DO}$ meet the national quality standards for Class III.

Table2 Water quality identification index of West Lake in different monitoring time

\begin{tabular}{ccccccccc}
\hline \multirow{2}{*}{$\begin{array}{c}\text { Momitoring } \\
\text { time }\end{array}$} & $\begin{array}{c}\text { Objects of } \\
\text { function zone }\end{array}$ & DO & $\mathrm{COD}_{\mathrm{Cr}}$ & $\mathrm{COD}_{\mathrm{Mn}}$ & $\mathrm{NH}_{3} \mathrm{~N}$ & $\mathrm{TN}$ & $\mathrm{TP}$ & $I_{w q}$ \\
\cline { 3 - 7 } & Class V & 3.10 & 3.10 & 5.40 & 3.40 & 5.30 & 7.53 & 4.610 \\
May & Class V & 2.40 & 4.10 & 5.20 & 2.80 & 4.90 & 6.21 & 4.310 \\
Sep. & Class V & 4.40 & 4.80 & 6.11 & 5.80 & 7.32 & 9.44 & 6.331 \\
Dec. & Class V & 3.40 & 4.10 & 6.11 & 3.10 & 6.11 & 8.33 & 5.230 \\
Mar. & &
\end{tabular}

note: $P_{i}$ stands for single factor water quality identification index. $I_{w q}$ stands for comprehensive water quality identification index.

Seen from the assement result of the comprehensive water quality identification index $\left(I_{w q}\right)$, the walue of $I_{w q}$ in December is the highest with 6.331 , indicating that the water quality of West Lake is worse than the national quality standards for Class $\mathrm{V}$ but not at the black and odorous state. Three of the monitoring items is over the standard of the water environment function. Water environment quality is 1 grades wrose than the request of function zone ${ }^{[9]}$. The value of $I_{w q}$ in March is 5.230, which indicates that the water environment quality meet the national quality standards for Class $\mathrm{V}$. Three of the monitoring items is over the standard of the water environment function. ${ }^{[9]}$. The value of $I_{w q}$ in May and September is 4.610 and 4.310, showing that the water environment quality confirm to the national quality standards for Class IV. Only one of the monitoring items is over the standard of the 
water environment function. ${ }^{[9]}$.

\section{Conclusions}

The water environment quality of West Lake in Guangdong Ocean University was assessed based on the water quality investigation data in May, September and December of 2013 and March of 2014. The main conclusions were as follow:

$\mathrm{TP}, \mathrm{TN}$ and $\mathrm{COD}_{\mathrm{Mn}}$ are the main pollutants of West Lake. The average concentrations of TP in West Lake during all the monitoring time are not able to confirm to the national quality standards for Class V. TP is the key pollutant of West Lake. TN and COD ${ }_{\mathrm{Mn}}$ are also worse than the national quality standards for Class V in March and December.

The water quality at wet season ,i.e. September and May is better than that at dry season, i.e. March and December. The value of $I_{w q}$ in May and September is 4.610 and 4.310. The water environment quality confirming to the national quality standards for Class IV. Only one of the monitoring items is over the standard of the water environment function. The water quality in December is the worst. The value of $I_{w q}$ is 6.331 . The water quality of West Lake is worse than the national quality standards for Class $\mathrm{V}$ but not at the black and odorous state.

The water quality of West Lake is affected largely by the domestic sewage of the dormitory and cafeteria because of its smaller catchment area.

\section{Acknowledgements}

This work was financially supported by University Innovation Research and Training Program of Guangdong Ocean University (CXXL12035).

\section{References}

[1] Zuxin Xu, Yaping Jiang: Journal of Tongji University(Natural Science) Vol.37(2009), p. 1044-1048.

[2] Guohong Ma, Fangfang Guo, Tao Xu, Guojing Xu, Fei Liu, Minglei Zhang, Xinghua Du, Jinping Chen: Journal of Shandong Agricultural University(Natural Science) Vol.44(2013), p.372-378

[3] Hui Geng, Jianzhi Xie, Shuqing Liu: Journal of Agricultural University of Hebei (Natural Science) Vol.34(2011), p.93-98

[4] Zhifeng Fan, Liqing Wang, Linxing Chen, Yan Li, Ziran Peng, Gaohua Ji: Journal of Shanghai Ocean University Vol.18(2009), p. 314-320.

[5] Jianping Lai, Wenbin Zhou, Maolan Wang: Yangtze River Vol.44(2013), p. 84-87

[6] Dajie Yang: Water Resources and Hydropower Engineering Vol.45(2014), p.28-30

[7] State Environmental Protection Administration of China "Environment Quality Standard for Surface Water (GB 3838-2002)".

[8] Zuxin Xu: Journal of Tongji University(Natural Science) Vol.33(2005), p. 321-325.

[9]Zuxin Xu: Journal of Tongji University(Natural Science) Vol.33(2005), p. 482-488. 